\title{
Roche and Promega back in court for Taq
}

[SAN FRANCISCO] The seven-year battle over ownership of rights to the enzyme Taq DNA polymerase came back to court this month.

A San Francisco court will hear allegations that the US patent held by Swiss drug lently obtained by the original applicant, Cetus Corp. Roche is being challenged by Promega Corp, a laboratory supply company based in Madison, Wisconsin, which has licence granted by Cetus.

The dispute dates from Roche's 1991 company Hoffmann-La Roche was fraudubeen selling Taq since the late 1980s under a

purchase of the rights to the polymerase chain reaction (PCR) from Cetus in a $\$ 300$ million deal. At the time, the Swiss company asked Promega to stop selling Taq, claiming it violated the Roche-Cetus agreement. When Promega refused, Roche demanded higher royalties. Promega again refused, and in 1992 Roche filed a suit for breach of contract. The contract expired in 1995.

In November 1996, Roche received a broad European patent covering key PCR enzymes including Taq. At the time, company officials said the approval showed that

\section{US sanc tions hurt basic research in India}

[NEW DELHI] Sanctions imposed by the US government after India's nuclear tests in May 1998 have badly hit work at the Tata Institute of Fundamental Research (TIFR) in Mumbai (formerly Bombay), India's premier institution for physical and mathematical research.

Some $\mathbf{4 5}$ of the institute's scientists held an extraordinary meeting on 28 January. They said the situation was "serious" and that some projects may be abandoned if the sanctions were not lifted soon. They believe other research institutes in India have similar problems.

TIFR, funded by the Department of Atomic Energy, is one of 250 "entities" the US government claimed were helping India's nuclear and missile programmes. US government agencies were prevented from collaborating with these, and US firms require export licences to trade with them (see Nature 393, $197 \&$ 396, 206; 1998). Last month, the US government stopped seven scientists from the Fermi National Laboratory from attending an international conference on high-energy physics at TIFR.

Chemistry professor G. Krishnamoorthy, who organized the meeting, said that TIFR was suffering most from the denial of equipment and services from US firms. "The effects of sanctions began only after the publication of the entities list by the US Bureau of Export Administration in the middle of November," he said. "We have received a large number of denials from companies because they apparently want to play it safe [with the US government]".

A laser bought from Spectra-Physics at a cost of \$250,000 in March 1998 for studying biomolecules has been idle for months because the company is refusing to ship any attachments or to service it, despite a oneyear warranty. A \$100,000 computer bought from Silicon Graphics "for solving complex problems in theoretical physics" is lying unused, as the company has refused to replace defective processors. Work stations

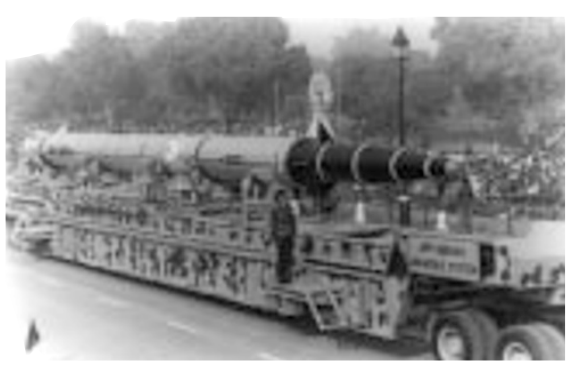

Hit parade: the Agni missile makes its New Delhi debut in last month's Republic Day celebrations.

and servers bought from Digital are not being serviced. Sorvall has refused to deliver high-speed ultracentrifuges. Malaria researcher Shobhona Sharma says that Sigma (India) has been instructed not to supply chemicals or biochemicals. Optical and electronic components from Thorn Labs have been denied and, says Krishnamoorthy, "this is only a sample".

Scientists say that research using equipment supplied before the sanctions and not working properly has stopped. "Where new purchases of materials and equipment have been denied, the ongoing research projects have either had to be abandoned or toned down," says Krishnamoorthy. Although some items can be obtained from other countries, he says, this is impossible in many cases. "Denial of products from the USA would place us in a situation where we will not be able to select the best approach in our research."

TIFR scientists feel the sanctions have "gone far beyond the stated purpose of limiting India's nuclear, missile and military activity" and are hurting basic science. Some suspect that the heads of the country's scientific agencies are downplaying the issue because of vested interests.

TIFR scientists fear that if this continues "we may not be able to attract bright students and scientists" - a serious problem since many of its scientists are due to retire in the next few years. K.S.Jayaraman expert scientific examiners recognized the biochemical facts that distinguish the Cetus invention from prior work. A year later, however, the Australian Patent Office withdrew rights to the enyzme in its native form, in response to a challenge led by New England Biolabs and Bresatec (now Bresagen) on the basis that other researchers knew of Taq before Cetus made its claim (see Nature 390, 327; 1997). The Australian Patent Office upheld Roche's claim to recombinant Taq.

Promega argues that Roche's Taq patent is invalid because Taq had been anticipated by earlier work. Its lawyers claim that Cetus was aware that the thermostable DNA polymerase it had extracted from E. coli was the same as enzymes from the same organism that had already been described in the literature, and so deliberately misled the US Patent and Trademark Office.

The US District Court Judge Vaughan Walker had ruled in 1996 that Taq inventors made four material misrepresentations or omissions in their patent application that could have misled patent examiners. Now he must decide whether those misrepresentations were intentional, and if Cetus scientists and executives knew their invention was not novel and withheld information.

Proceedings began on 1 February with Arthur Kornberg, winner of the 1959 Nobel Prize in Medicine, on the witness stand. As he explained the isolation of DNA polymerase, Judge Walker - in what has become a leitmotiv - urged participants to stick to the point. In cross-examination, Roche lawyers then showed that two of Kornberg's exhibits included erroneous details.

More cut and thrust can be expected in the two weeks scheduled for the trial. Using internal memos and expert testimony such as Kornberg's, Promega hopes to show that David Gelfand, the primary inventor on the Taq patent and manager of the Taq project at Cetus, misrepresented facts about Taq activity, nuclease contamination, measured fidelity, $\mathrm{pH}$ profile and other characteristics that Cetus used to show the invention was novel.

Promega plans to lay out 13 instances of misrepresentation or material omission in the patent filing. The documents and other information show that "the inventors chose to mislead, misrepresent and omit critical information time and again", writes attorney James Troupis in Promega's trial brief.

Roche responds that the applicants either did not know about the undisclosed information or did not believe it was important. The Cetus discoveries were distinct from earlier ones and the scientists involved are innocent of deception, writes Roche attorney Brian Poissant, adding that some exaggeration and advocacy in a patent claim does not amount to fraud.

Sally Lehrman 